\title{
The Impact of Entrepreneurial Ability on Innovation Performance of Chinese New Company: Based on the Mediating Role of Business Model
}

\author{
Xiong Wang ${ }^{1} \&$ Sarana Photchanachan ${ }^{2}$ \\ ${ }^{1} \mathrm{Ph}$. D. Candidate, School of Management, Shinawatra University, Thailand \\ ${ }^{2}$ Management, School of Management, Shinawatra University, Thailand \\ Correspondence: XiongWang, School of Management, Shinawatra University, Thailand. E-mail: \\ klfb8868@outlook.com
}

Received: August 9, 2021

Accepted: September 10, 2021

Online Published: September 18, 2021

doi:10.5539/ijbm.v16n11p12

URL: https://doi.org/10.5539/ijbm.v16n11p12

\begin{abstract}
At present, researches on business models generally focus on the deduction of theoretical models and case studies, and there are relatively few related quantitative studies. From the perspective of business model, this paper empirically studies the relationship between business model, entrepreneurial ability and innovation performance, taking newly established companies in Shanghai as the research object. The results show that Entrepreneurial Ability positively correlated with innovative business model and efficient business model. The innovative business model and efficiency business model is positively correlated with innovation performance. Business model is the intermediate mechanism of transforming entrepreneurial ability into innovative firm performance, and the design of business model is helpful to improve the survival rate and profitability of entrepreneurial firms.
\end{abstract}

Keywords: entrepreneurial ability, innovative business model, efficient business model, innovation performance

\section{Introduction}

With the development of information technology and "Internet +", many new company appear in China. However, the survival rate of new company is low and the existence time is generally short. That is to say, the survival rate of new company is low and the existence time of new company is short. For new company, reasons such as entrepreneurial resources, entrepreneurial atmosphere, entrepreneurial opportunities and so on May become the factors restricting the growth of new company. However, entrepreneurial ability, as an essential and key factor in the early establishment of a new company, is very important at the beginning of entrepreneurial ability. At the same time, the development of new company cannot be separated from the proper choice of business model. Business model, as the theoretical basis for revealing how company do business and create value for users, is of obvious importance to new company. Therefore, how new company design business model has attracted wide attention from the academic and business circles.

For new company, the importance of entrepreneurial ability and business models is self-evident. In the actual study, we always put the entrepreneurial ability and business model to the enterprise the influence of separate. However, business model as a reveal how firms value creation theory, between entrepreneurial ability and corporate performance must bear the certain role in the mechanism of action, Therefore, the influencing mechanism of entrepreneurial ability, business model and firm performance is worth further study.

\section{Literature Review}

\subsection{Entrepreneurial Ability}

Research on entrepreneurial ability, Some scholars focus on opportunities. Timmons (2014) argued that entrepreneurial ability development comes from the recognition of entrepreneurial opportunities, entrepreneurial companies the ability to recognize opportunities is the most important ability in the process of new company, it can directly determine new ventures to create successful or not, and will be with the mature development of new 
ventures and entrepreneurial ability will also along with the continuously promoted the growing of the company, similarly, Shane (2003) is from the perspective of entrepreneurial opportunities, think the company the most important thing is to explore opportunities in the entrepreneurial process and opportunities for the development of ability. Chinese scholars Guo Runping (2019) study also focused on the importance of entrepreneurial opportunities for entrepreneurial ability, think that the ability of companies to identify and develop business opportunities is the most important in the process of company business capacity, and part of the scholars emphasized the importance of resources, such as Hoskisson points out that the resource is the company to create value and profits, all the elements of production activities, as a prerequisite for company survival and development, daily operation are inseparable from the resource support for the company, in the process of entrepreneurial ability, need new ventures have about all kinds of resources in the process of entrepreneurial coordination ability. According to the relevant research of Lilia et al. (2021), the entrepreneurial resources used in the process of entrepreneurial ability mainly include space, capital, talents, management and other resources.

In a word, from the perspective of entrepreneurial process, opportunities and resources are the two core issues of entrepreneurial process. Koryak (2015) entrepreneurial ability dimensions related to the opportunity of further subdivided, so divided into three dimensions - opportunity recognition ability, development ability and the resources ability, companies in the process of entrepreneurial ability need to make a balance between the opportunities and resources, if excessive pursuit of opportunity will be out of actual business resources and the allocation of resources caused by unreasonable use, excessive use of resources will increase the company operating costs (Shang Shuqin etc., 2019). Previous scholars focused their research on entrepreneurial ability on opportunities and resources in the entrepreneurial process. Therefore, this paper believes that entrepreneurial ability is the ability of new companies to identify and develop opportunities, integrate and develop resources, and realize entrepreneurial opportunities. Considering the importance of opportunities and resources to the success of entrepreneurial ability, entrepreneurial ability is considered as the ability of entrepreneurs to identify opportunities, integrate and develop resources, and realize entrepreneurial opportunities.

\subsection{Business Model}

Business model describes how companies profitable design, this kind of business model is the concept of general overview of the commercial framework, including descriptions of customers, products, services, information flow, the main concern is the company foundation design in the process of actual operation. The business model reveals the basic principle of how to create value, transfer value and obtain value between companies and external stakeholders in the actual transaction process. At the same time, nine basic building blocks are proposed to display the business model of companies. Baden Fuller (2010) argue that business model is the company by way of profit creation, distribution, value, the elements of business model including the resources, capabilities, products, customers, technology and market. Demil and Lecocq (2010) argue that business model by creating value for customers and the company's resources and capabilities, organizational structure, value proposition, the costs and benefits the five basic elements. George \& Bock (2011) through the analysis of the business model of small and medium-sized companies, put forward the process of selecting the business model company, is the company value, resources and trading structure, three dimensions of organizational design. Achtenhagen (2013) also think that business model is a business structure of creating value for customers, including market participants in the business structure, value chain position, customers and suppliers. Saebi and Foss (2015) believe that business model is the design of transaction content, structure and governance between focus companies and trading partners. Similarly, Kulins (2016) defined business model as the design of transaction content, transaction structure and transaction governance with partners for the purpose of creating customer value through comparative analysis of 41 new companies. Xiao et.al (2020) believes that sustainable business model innovation is a comprehensive innovation that enterprises pursue value proposition, value creation, element acquisition and value network with sustainable development as the guidance

\subsection{Innovation Performance}

Performance is one of the most important structures in strategic management. As for its conceptualization, dimension and measurement, it has tended to be recognized, but the actual measurement process will be different due to the influence of industry and company characteristics. Since the foundation work of Venkatraman \& Ramanujam (1986), corporate performance has been regarded as a multi-dimensional structure, including corporate financial and operational performance. If considering the interests of stakeholders and corporate performance may also include other aspects, such as profitability, growth of the market value, customer and employee satisfaction as well as social and environmental responsibility, many studies acknowledge company performance has multidimensional nature, but in actual measurement, for the convenience of operation, the companies tend to adopt the single index to measure business performance, and this kind of structure is 
expressed as a one-dimensional structure. In addition, new ventures invest a lot of money at the beginning of creation, so the beginning usually don't want to take the initiative to disclose the real financial data (Gibcus \& Kemp, 2003) and the entrepreneurs may have a profit targets, such as independence, growth or corporate sustainability, that is why many study used subjective, based on the perception of indexes, to measure the performance of the structure of the multidimensional nature. Subjective measures of perception include: the owner's assessment of the performance of its main competitors in assessing profitability, return on investment and financial objectives. Such as profitability, market value, customer and employee satisfaction, and social and environmental responsibility (Pucci, 2017), or sales growth, customer satisfaction, return on investment, customer retention, and competitive position. According to the literature on performance measurement of new companies, considering that companies may not be willing to disclose financial indicators specifically, in this study, company performance is evaluated by subjective measurement indicators.

\section{Hypothesis Development and Research Model}

\subsection{Entrepreneurial Ability and Business Model}

Chinese scholars (Zhang JY., 2013, Yao L., 2020) have found that in the process of entrepreneurial ability, the cultivation of entrepreneurial ability needs to attract the attention of entrepreneurs, and the level of entrepreneurial ability will have an impact on the business model design of enterprises. Business model design is the design mechanism of transaction content, transaction structure and transaction governance between enterprises and external stakeholders. Enterprises need to consider two points when designing business models (Zott, 2011): first, business models should create value for partners, and second, the scope of business model design should be taken into account. In view of the fact that start-up enterprises have the most incomplete system at the beginning of their growth life cycle and are greatly affected by start-up resources, if the efficiency and innovation of enterprise operation are taken into account at the same time, resources will be wasted due to the unclear business model. Enterprises that choose both efficient and innovative business models will accumulate the start-up rent to the new company and stakeholders. Therefore, it is unlikely for the new company to give consideration to both innovation and efficiency at the same time. When choosing a business model, they usually choose one between the innovative business model and the efficient business model. Innovative business model is to point to the company to undertake transaction with partner will adopt new transaction activity, new transaction connection way or new transaction governance way, its essence is to provide new solution for transaction partner, have better customer experience. In the era of rapid development of Internet technology and advanced information iteration and update, it is likely that the focus enterprises will find new ways of transaction. The essence of a novel business model is to provide a new value experience for trading partners, so new company need to be able to discern the potential needs of customers and be good at seizing business opportunities. Startup on content about trading, trade structure and trade governance mechanism of the new idea, internal and external resources reasonable allocation, tend to set up ahead of the competition of business model, namely, innovative design business model, in order to gain the first mover advantage of the company, better value creation activities, opportunities can be converted to obtain sustainable competitive advantage. Hence, we propose the following hypothesis:

H1a: Entrepreneurial Ability positively correlated with innovative business model.

Aspara (2010) and Zott (2011) argued that for new company, in addition to innovative business model, another way for new company to create wealth is to copy the business model of the existing market. In other words, entrepreneurs can choose to imitate the model similar to the existing company, but create value in a more efficient way. This business model is called efficient business model. Enterprise business ability is strong, can identify external knowledge and information, more keenly help entrepreneurs to manage and control the uncertainty in the process of entrepreneurial ability, to reduce the impact of environmental uncertainty, entrepreneurial company can use their efficient resource integration ability, establish efficient resource allocation system, to integrate the value chain and industrial chain, Precise and efficient matching of resource supply and demand parties can be achieved to reduce decision-making costs and operating costs for enterprises and partners involved in the transaction, thus reducing transaction costs and transaction risks of enterprises and promoting the design of efficient business models. Hence, we propose the following hypothesis:

H1b: Entrepreneurial Ability is positively correlated with efficient business model.

\subsection{Business Model and Innovation Performance}

The essence of innovative business model is to provide new value experience to trading partners. In order to obtain good customer experience, customers tend to have stronger purchase intention and pay higher prices for products or services. In addition, innovative business models can often conduct creative transactions in the 
existing market or even create new markets, provide new solutions for customers, and attract new customers to join. At this time, enterprises can adopt a number of measures to improve user engagement, which is conducive to enterprise performance. On the other hand, the higher the novelty of the business model design, the fewer alternatives exist in the market, the focus company may not be easy to obtain alternatives for doing business, the higher the conversion cost of the transaction partners cooperating with the focus company, the higher the focus company's bargaining power, and the more obvious the performance improvement of the focus company. Hence, we propose the following hypothesis:

H2a: The innovative business model is positively correlated with innovation performance of the new company.

The essence of the efficiency business model is to reduce the transaction cost between the enterprise and the transaction partner and improve the transaction efficiency. This is mainly achieved by standardizing the interactive interface, reducing information asymmetry and simplifying the transaction process. On the one hand, the convenient transaction process accelerates the transaction processing speed and attracts more stakeholders to join the focus enterprise. For the original customers, the low transaction cost and the increase of transaction frequency will lead to strong user stickiness. On the other hand, the reduction of transaction costs reduces the information asymmetry and transaction risks, thus reducing the opportunistic behaviors of suppliers and customers. The focus enterprises have higher bargaining power and improve their performance. Hence, we propose the following hypothesis:

$\mathrm{H} 2 \mathrm{~b}$ : The efficiency business model is positively correlated with innovation performance of the new company.

\subsection{The Mediating Role of Business Model}

Business model design need to customer demand as the guidance, the process of the integration of enterprise to seek the external environment and internal resources, create value for enterprises and stakeholders, for new ventures, business model design is the process of enterprise resources, the ability to interact with the external environment constantly, the process of successful new company have development business opportunities, coordination of resources integration of entrepreneurial ability, Its business model is in line with the development of company, so as to gain competitive advantages in established industries and improve performance (Wenliang, 2011). Hence, we propose the following hypothesis:

H3: Business model mediates the relationship between entrepreneurial ability and innovation Performance.

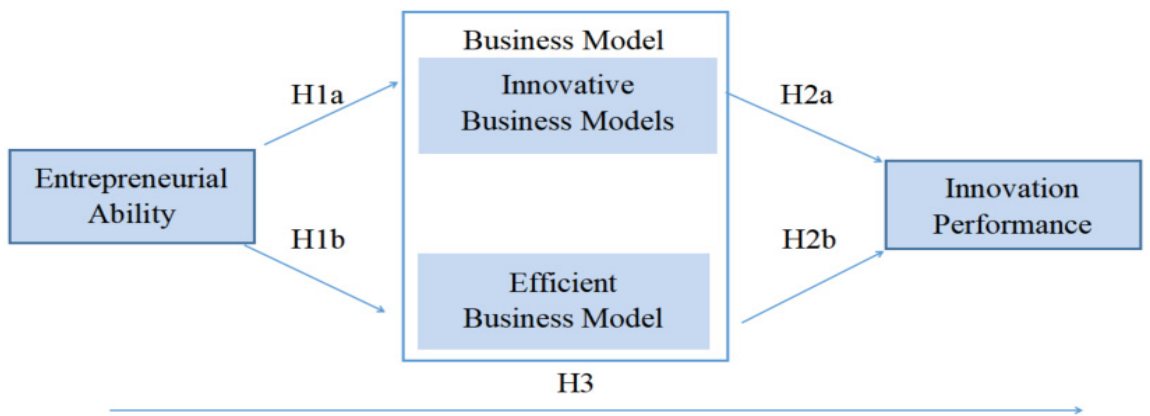

Figure 1. Research model

\section{Methodology}

\subsection{Sample Size and Data Collection}

This study adopts snowball sampling to collect sample data. The sample survey objects are newly established companies in Shanghai, China. Considering the new companies are mainly distributed in Shanghai new companies park (Shanghai new companies park: the gathering place of most new companies); Incubation base (incubation base: the government places most breeding companies in a centralized place), etc. In these areas, snowball sampling is adopted to collect data. snowball sampling can improve the efficiency of data collection and reflect the effectiveness of data of most new companies. A total of 530 questionnaires were sent out through professional questionnaire survey websites and mailboxes, and 456 were recovered, the recovery rate was $86 \%$. Among them, 411 were valid questionnaires. 


\subsection{Questionnaire Design and Measurement}

All the measurement items used in this study are adopted from previous research studies and have been validated. The questionnaire consisted of two parts. The first part is about the demographic information of the respondents, such as gender, age, etc. The second part contains all the test items of constructs in the conceptual framework. All items in this part are based on the five-point Likert Scale ( 1 ="Strongly disagree", 5 = "Strongly agree").

\section{Data Analysis and Results}

\subsection{Descriptive Statistics Analysis}

As Table 1 shows, a majority of the respondents was male. For new company, there are more men. There are more people under 35 years old, accounting for $63 \%$, indicating that entrepreneurs in Shanghai are relatively young. Bachelor's degree mainly, the company established years concentrated within $\leq 6$ years. The industry was dominated by Internet $(25.55 \%)$ and manufacturing $(37.47 \%)$.

Table 1. Demographic profile of the respondents

\begin{tabular}{llll}
\hline \multirow{2}{*}{ Demographics Characteristics } & & Frequency & $\%(\mathrm{n}=411)$ \\
\hline \multirow{2}{*}{ Gender } & Male & 198 & $48.18 \%$ \\
& Female & 213 & $51.82 \%$ \\
Age & $\leq 25$ & 126 & $30.66 \%$ \\
& $26-35$ & 133 & $32.36 \%$ \\
& $36-45$ & 97 & $23.6 \%$ \\
Education Level & $\geq 45$ & 55 & $13.38 \%$ \\
& High school or less Diploma & 77 & $18.73 \%$ \\
& Bachelor's Degree & 305 & $74.21 \%$ \\
Company establishment years & Master's Degree & 19 & $4.62 \%$ \\
& Doctoral Degree & 10 & $2.43 \%$ \\
& $0-2$ years & 100 & $24.33 \%$ \\
& 2-4years & 159 & $38.69 \%$ \\
& $4-6 y e a r s$ & 101 & $24.57 \%$ \\
Industry & 6-8years & 51 & $12.41 \%$ \\
& Internet & 105 & $25.55 \%$ \\
& Manufacturing & 154 & $37.47 \%$ \\
& Service & 62 & $15.09 \%$ \\
& Wholesale \& retail & 65 & $15.81 \%$ \\
\hline
\end{tabular}

\subsection{Reliability and Validity}

In this paper, Cronbach's Alpha coefficient method, a widely used research method, is adopted as the reliability test method. SPSS24.0 is used to analyze the reliability of the involved independent variables, two intermediary variables and dependent variables. The Cronbach's Alpha coefficient of each variable is 0.945, 0.902, 0.9849, 0.935. The Cronbach's alpha for each build was greater than 0.7 , indicating that our survey instrument has a high level of reliability (Nunnally,1978).

The scale in this paper borrows from the maturity scale to ensure the reliability of content validity to a certain extent. To test whether the data were suitable for factor analysis, KMO and Bartler sphericity tests were performed for each variable with SPSS. Table 2 shows that the factor loading of each variable measurement problem values were greater than 0.6 , indicating that the measured scale has good construction validity. Meanwhile, the KMO value of each variable in Table 2 is greater than 0.7. Bartlett's test is significant at the level of 0.000 , indicating that the variable is suitable for factor analysis and has a certain validity, which can be further studied. 
Table 2. Results of Validity and Reliability Analysis ( $\mathrm{N}=411)$

\begin{tabular}{|c|c|c|c|c|c|c|}
\hline \multicolumn{2}{|l|}{ Factors } & Indicators & $\begin{array}{l}\text { Factor } \\
\text { Loadings }\end{array}$ & $\begin{array}{l}\text { Accumulative contribution } \\
\text { rate }(\%)\end{array}$ & KMO & Cronbach's Alpha \\
\hline \multirow{8}{*}{\multicolumn{2}{|c|}{$\begin{array}{l}\text { Entrepreneurial } \\
\text { Ability }\end{array}$}} & Q1 & 0.838 & \multirow{7}{*}{$73.088 \%$} & \multirow{7}{*}{0.945} & \multirow{7}{*}{0.938} \\
\hline & & Q2 & 0.906 & & & \\
\hline & & Q3 & 0.842 & & & \\
\hline & & Q4 & 0.857 & & & \\
\hline & & Q5 & 0.837 & & & \\
\hline & & Q6 & 0.825 & & & \\
\hline & & Q7 & 0.876 & & & \\
\hline & & Q8 & 0.876 & \multirow{5}{*}{$77.387 \%$} & \multirow{5}{*}{0.902} & \multirow{5}{*}{0.926} \\
\hline \multirow{4}{*}{$\begin{array}{l}\text { Innovative } \\
\text { Model }\end{array}$} & \multirow{4}{*}{ Business } & Q9 & 0.895 & & & \\
\hline & & Q10 & 0.859 & & & \\
\hline & & Q11 & 0.890 & & & \\
\hline & & Q12 & 0.877 & & & \\
\hline \multirow{4}{*}{$\begin{array}{l}\text { Efficient } \\
\text { Model }\end{array}$} & \multirow{4}{*}{ Business } & Q13 & 0.884 & \multirow{4}{*}{$79.020 \%$} & \multirow{4}{*}{0.849} & \multirow{4}{*}{0.911} \\
\hline & & Q14 & 0.904 & & & \\
\hline & & Q15 & 0.908 & & & \\
\hline & & Q16 & 0.859 & & & \\
\hline \multirow{6}{*}{\multicolumn{2}{|c|}{$\begin{array}{l}\text { Innovation } \\
\text { Performance }\end{array}$}} & Q17 & 0.883 & \multirow{6}{*}{$76.402 \%$} & \multirow{6}{*}{0.935} & \multirow{6}{*}{0.938} \\
\hline & & Q18 & 0.886 & & & \\
\hline & & Q19 & 0.874 & & & \\
\hline & & Q20 & 0.864 & & & \\
\hline & & Q21 & 0.877 & & & \\
\hline & & Q22 & 0.860 & & & \\
\hline
\end{tabular}

\subsection{Correlation Analysis}

Correlation analysis is a method to analyze the degree of interdependence between one variable and another, without focusing on causal relationship between variables. The correlation analysis of each research variable can help to understand the correlation between variables, and the preliminary prediction of whether the relationship between variables is consistent with the hypothesis of this study. Table 3 presents correlations among numeric variables. There is a significant correlation between the four main variables of entrepreneurial ability, innovative business model, efficient business model, innovation performance. There is a significant impact from entrepreneurial ability $(\mathrm{r}=0.721, \mathrm{p}<0.01)$ on innovative business model. There is a significant impact from entrepreneurial ability $(\mathrm{r}=0.663, \mathrm{p}<0.01)$ on efficient business model. There is a significant impact from entrepreneurial ability $(\mathrm{r}=0.697, \mathrm{p}<0.01)$ on innovation performance. There is a significant impact from innovative business model $(\mathrm{r}=0.684, \mathrm{p}<0.01)$ and efficient business model $(\mathrm{r}=0.668, \mathrm{p}<0.01)$ on innovative business model. The results of this correlation analysis provide preliminary evidence for subsequent hypotheses.

Table 3. Correlation matrix

\begin{tabular}{|c|c|c|c|c|c|c|c|c|c|}
\hline Variables & 1 & 2 & 3 & 4 & 5 & 6 & 7 & 8 & 9 \\
\hline 1.Gender & 1 & & & & & & & & \\
\hline 2.Age & $.228 * *$ & 1 & & & & & & & \\
\hline 3.Education Level & .018 & $.197 * *$ & 1 & & & & & & \\
\hline $\begin{array}{l}\text { 4.Company establishment } \\
\text { years }\end{array}$ & $.496 * *$ & $.445^{*}$ & $.389 *$ & 1 & & & & & \\
\hline 5.Industry & $.783 * *$ & $.168 * *$ & $.538^{*}$ & $.807 * *$ & 1 & & & & \\
\hline 6.Entrepreneurial Ability & $.3353^{*}$ & $.536 * *$ & $.463 * *$ & $.488 * *$ & $.454 * *$ & 1 & & & \\
\hline 7.Innovative Business Model & $.580 * *$ & $.594 * *$ & $.643 * *$ & $.542 * *$ & $.535 * *$ & $.721^{* *}$ & 1 & & \\
\hline 8.Efficient Business Model & $.037 * *$ & $.011 * *$ & $.207 * *$ & $.082 * *$ & $.085^{* *}$ & $.663 * *$ & $.632 * *$ & 1 & \\
\hline 9.Innovation Performance & $.407 * *$ & $.406 * *$ & $.441 * *$ & $.468 * *$ & $.457 * *$ & $.697 * *$ & $.684 * *$ & $.668 * *$ & 1 \\
\hline
\end{tabular}

Notes. $* \mathrm{p}<.05 ; * * \mathrm{p}<.01 ; * * * \mathrm{p}<.001$. 


\subsection{Hypothesis Testing Result}

As shown in Table 4. Model 1 tests the influence of control variables on innovation performance, and Model 2 is based on the control variable, and the influence of entrepreneurial ability on the innovation performance is added. It can be seen from Model 2 that the enhancement of entrepreneurial ability will improve the innovation performance $(\beta=0.668, p<0.001)$. Model 3 and Model 4 test the impact of entrepreneurial ability on the innovative business model. According to the test results of the models, entrepreneurial ability has a significant impact on the innovative business model $(\beta=0.729, \mathrm{p}<0.001)$, Thus, Hypothesis $1 \mathrm{a}$ was supported.

Model 6 as the third step of the mediating effect test, is the result of the influence of innovative business model on innovation performance. The innovative business model $(\beta=0.415, p<0.001)$ is positively correlated with innovation performance. Hypothesis $2 \mathrm{a}$ was supported. The $\mathrm{R}^{2}$ value of the model increased significantly from 0.126 to $0.567, \beta=0.385, p<0.001$ indicating that the innovative business model partially mediated the relationship between entrepreneurial ability and innovation performance.

As shown in Table 5. Model 7 and Model 8 test the impact of entrepreneurial ability on the innovative business model. According to the test results of the models, entrepreneurial ability has a significant impact on the innovative business model $(\beta=0.647, \mathrm{p}<0.001)$, Thus, Hypothesis $1 \mathrm{~b}$ was supported.

Model 10 is the result of the influence of efficient business model on innovation performance. The efficiency business model $(\beta=0.376, p<0.001)$ is positively correlated with innovation performance. Hypothesis $2 \mathrm{~b}$ was supported. $\beta=0.444$ which is smaller than 0.688 before, and the $\mathrm{R}^{2}$ value of the model increased significantly from 0.126 to $0.579, \beta=0.444, p<0.001$ indicating that the efficient business model partially mediated the relationship between entrepreneurial ability and innovation performance. To sum up, Hypothesis 3 was supported, business model mediates the relationship between entrepreneurial ability and innovation Performance.

Table 4. Mediating effect test of innovative business model

\begin{tabular}{|c|c|c|c|c|c|c|}
\hline & \multicolumn{2}{|c|}{ Innovation Performance } & \multicolumn{2}{|c|}{ Innovative Business Models } & \multicolumn{2}{|c|}{ Innovation Performance } \\
\hline & Model 1 & Model 2 & Model 3 & Model 4 & Model 5 & Model 6 \\
\hline Education Level & $0.281 * *$ & 0.050 & 0.119 & 0.117 & $0.281^{* *}$ & 0.099 \\
\hline $\begin{array}{l}\text { Company } \\
\text { Establishment Years }\end{array}$ & 0.158 & 0.028 & $0.255^{*}$ & 0.057 & 0.158 & 0.052 \\
\hline Industry & 0.035 & 0.005 & 0.136 & 0.093 & 0.035 & 0.044 \\
\hline Entrepreneurial Ability & & $0.668^{* *}$ & & $0.729^{* *}$ & & $0.385^{* *}$ \\
\hline Innovative Business Models & & & & & & $0.415^{* *}$ \\
\hline $\mathrm{R}^{2}$ & 0.126 & 0.488 & 0.136 & 0.542 & 0.126 & 0.567 \\
\hline$\triangle R^{2}$ & 0.109 & 0.474 & 0.119 & 0.530 & 0.109 & 0.552 \\
\hline
\end{tabular}

Table 5. Intermediary effect test of efficient business models

\begin{tabular}{lllll}
\hline & \multicolumn{2}{l}{ Efficient Business Model } & \multicolumn{2}{l}{ Innovation Performance } \\
\cline { 2 - 5 } & Model 7 & Model 8 & Model 9 & Model 10 \\
\hline Education Level & 0.181 & 0.027 & $0.281^{* *}$ & 0.060 \\
Company & $0.249^{*}$ & 0.074 & 0.158 & 0.056 \\
Establishment Years & & & & 0.005 \\
Industry & 0.037 & 0.001 & 0.035 & $0.444^{* *}$ \\
Entrepreneurial Ability & & $0.647^{* *}$ & & $0.376^{* *}$ \\
Efficient Business Models & & & & 0.579 \\
$\mathrm{R}^{2}$ & 0.124 & 0.444 & 0.126 & 0.552 \\
$\Delta R^{2}$ & 0.107 & 0.430 & 0.109 & \\
\hline
\end{tabular}

\section{Conclusion}

\subsection{Conclusion}

This paper finds that there is a significant positive between entrepreneurial ability and business model and innovation performance. For new companies, on the basis of ensuring survival, continuous profit is the primary goal, so in order to reduce the chance of failure of new companies, cultivating entrepreneurial ability is essential; Cultivating entrepreneurial skills can help new company succeed and perform. However, the choice of business 
model is also crucial. Business model mediates the relationship between entrepreneurial ability and innovation Performance. The choice of business model can improve the success rate of entrepreneurial ability.

The results of this study show that for new company, cultivating entrepreneurial ability is very important. It is related to the choice of business model, the promotion of market shares and the development of the company. Specific view, entrepreneurial ability of the company can accurately identify market opportunities, think carefully about the advantages and disadvantages of industry enterprise business model, balance the company existing resources and external resources, to help company to choose the appropriate business model at the beginning. It is conducive to the design of innovative business model and efficient business model of new companies, and promote the development of future enterprises and the improvement of performance.

\subsection{Future Research}

The research mainly adopts questionnaire survey, data obtained mainly respondents fill out on the basis of subjective evaluation, although the measurement item as possible design of the questionnaire is easy to be understood, but the interviewer degree of understanding of the problem, personality differences are likely to cause the deviation of the data to a certain extent at the same time, the data sample is relatively insufficient, will lead to the lack of credible data, so in the future study, on the one hand, can be combined with the method of case study in a more accurate understanding of the corporate performance influence mechanism, to collect more samples at the same time, strengthen the can data reliability, and further improve the model.

\section{References}

Achtenhagen, L., Melin, L., \& Naldi, L. (2013). Dynamics of business models - strategizing, critical capabilities and activities for sustained value creation. Long Range Planning, 46(6), 427-442. https://doi.org/10.1016/j.lrp.2013.04.002

Baden-Fuller, C., \& Morgan, M. S. (2010). Business models as models. Long Range Planning, 43(2-3), 156-171. https://doi.org/10.1016/j.lrp.2010.02.005

Demil, B., \& Lecocq, X. (2011). Business model evolution: in search of dynamic consistency. Long Range Planning, 43(2-3), 227-246. https://doi.org/10.1016/j.lrp.2010.02.004

Franco-Santos, M., Kennerley, M., Micheli, P., Martinez, V., Mason, S., \& Marr, B. et al. (2013). Towards a definition of a business performance measurement system. International Journal of Operations \& Production Management, 27(8), 784-801. https://doi.org/10.1108/01443570710763778

George, G., \& Bock, A. J. (2011). The business model in practice and its implications for entrepreneurship $\begin{array}{lllll}\text { research. } & \text { Entrepreneurship } \quad \text { Theory } \& 3-111 .\end{array}$ https://doi.org/10.1111/j.1540-6520.2010.00424.x

Guo, R. P., Li, C., Management, S. O., \& University, J. (2019). The relationship among strategic experimentation, entrepreneurial capability and a new venture's competitive advantages: an empirical study in transitional economic context. Foreign Economics \& Management, 36(12), 3-12.

Hongjun, X., \& Yang, Z. (2020). Sustainable business model innovation: Review and prospect of research. Foreign Economics \& Management, (9), 3-18.

Jing, T., Yanfu, J. (2008). The theory construction and empirical test of the concept of entrepreneurial capability. Science of Science and Management of Science and Technology, (08), 52-57.

Kulins, C., Leonardy, H., \& Weber, C. (2016). A configurational approach in business model design. Journal of Business Research, 69(4), 1437-1441. https://doi.org/10.1016/j.jbusres.2015.10.121

Lilia Angélica Campo, Amar, P., \& Olivero, E. (2021). Interaction of Potential and Effective Entrepreneurial Capabilities in Adolescents: Modeling Youth Entrepreneurship Structure Using Structural Equation Modeling. https://doi.org/10.21203/rs.3.rs-537148/v1

Lixia, Y., \& Gong, Q. (2020). Business Model analysis of data service enterprises based on knowledge management -- a case study of Hangzhou F Technology Co., LTD. Science and Technology Management Research, 40(10), 227-234.

Mcgahan, A. M., \& Porter, M. E. (2015). How much does industry matter, really? Strategic Management Journal, 18(S1), 15-30. https://doi.org/10.1002/(SICI)1097-0266

Saebi, T. F., \& Nicolai, J. (2015). Business models for open innovation: matching heterogeneous open innovation strategies with business model dimensions. European Management Journal: EMJ, 33(3), 201-213. https://doi.org/10.1016/j.emj.2014.11.002 
Shane, S., \& Venkataraman, S. (2000). The promise of entrepreneurship as a field of research. Academy of Management Review, 25(1), 217-226. https://doi.org/10.1007/978-3-540-48543-8_8

Venkatraman, N., \& Ramanujam, V. (1986). Measurement of business performance in strategy research: a comparison of approaches. The Academy of Management Review, 11(4), 801-814. https://doi.org/10.5465/AMR.1986.4283976

Wirtz, B. W., Schilke, O., \& Ullrich, S. (2010). Strategic development of business models: implications of the web 2.0 for creating value on the internet. Long Range Planning, 43(2-3), 272-290. https://doi.org/10.1016/j.lrp.2010.01.005

Zhang, Y., Wang, X., School, B., University, N., \& Tianjin. (2011). Empirical study on prior experience, learning style and entrepreneurial competence. Journal of Management Science. (3), 1-12.

Zott, C., Amit, R., \& Massa, L. (2011). The business model: recent developments and future research. Journal of Management, 37(4), 1019-1042. https://doi.org/10.1177/0149206311406265

\section{Copyrights}

Copyright for this article is retained by the author(s), with first publication rights granted to the journal.

This is an open-access article distributed under the terms and conditions of the Creative Commons Attribution license (http://creativecommons.org/licenses/by/4.0/). 